\title{
Polyagglutinating and non-typable strains of Pseudomonas aeruginosa in cystic fibrosis
}

\author{
T. L. PITT, JANE MacDOUgALL, ANDREA R. L. PENKETH* and E. MARY COOKE
}

Division of Hospital Infection, Central Public Health Laboratory, 61 Colindale Avenue, London NW9 5HT and ${ }^{` C a r d i o t h o r a c i c ~ I n s t i t u t e, ~ B r o m p t o n ~ H o s p i t a l, ~ F u l h a m ~ R o a d, ~ L o n d o n ~ S W 7 ~}$

\begin{abstract}
Summary. Serologically polyagglutinating (PA) and non-typable (NT) strains of Pseudomonas aeruginosa are frequently isolated from cystic fibrosis (CF) patients, but are uncommon in other patients. From serologically typical parent strains, we isolated two variants (one PA, the other NT) which differed from the parent in bacteriophage susceptibility or in sensitivity to the bactericidal action of normal human serum. The PA and NT variants (strains $7 / 1$ and $18 \mathrm{~S}$ respectively) reacted with antiserum to the parent strains 7 and $18 \mathrm{R}$ but did not absorb homologous specific $\mathrm{O}$ antibody from antiserum to the parent strains. In contrast the parent strains absorbed anti-PA and anti-NT antibodies from antisera to the variant strains. The yield of lipopolysaccharide (LPS) from acetone-dried cells of the parent strain 7 was similar to that of the PA derivative; but the NT strain $18 \mathrm{~S}$ yielded only half the LPS of its parent strain. LPS of the variant $7 / 1$ gave a banding profile by SDS-PAGE similar to that of the parent LPS 7 , but lacked high-molecular-weight components. LPS of the variant $18 \mathrm{~S}$ appeared to be grossly different in profile from LPS 18R. Of 533 isolates of $P$. aeruginosa that were tested with $\mathrm{O}$ antisera and with antisera to the two variants, $15 \%$ were $\mathrm{O}$-typable and $22 \%$ were O-non-typable; $26 \%$ reacted with anti-PA serum alone, $10 \%$ with anti-NT serum alone, and $27 \%$ were agglutinated by both sera. There was a statistically significant correlation between serum sensitivity of CF isolates and their reaction with the PA or NT antisera.
\end{abstract}

\section{Introduction}

Pseudomonas aeruginosa is serologically heterogeneous and at least 17 lipopolysaccharide (LPS) type-specific $\mathrm{O}$ antigens have been described (Liu et al., 1983). The detection of these antigens by agglutination forms the basis of most $\mathrm{O}$-serotyping procedures, and approximately $93 \%$ of clinical hospital isolates can be allocated to a specific $O$ type (Pitt, 1981). However a recent study by Penketh $e t$ al. (1983) of 49 patients with cystic fibrosis (CF) who had respiratory infections with $P$. aeruginosa, showed that a specific $O$ serotype was detected in only $32 \%$ of 109 isolates from these patients. Approximately half $(55 \%)$ of the cultures were agglutinated by three or more $\mathrm{O}$ antisera and were termed polyagglutinable (PA) and $9 \%$ were nontypable (NT), i.e., they did not react with any of the $\mathrm{O}$ antisera. Furthermore, PA and NT cultures were often sensitive to the bactericidal action of fresh normal human serum. Hancock et al. (1983) also found that the majority of 26 isolates from CF sputum were serologically PA or NT and that LPS

Received 5 Mar. 1985; revised version accepted 5 Jul. 1985. of these cultures was deficient in oligosaccharide $\mathrm{O}$ specific side chains.

We set out to investigate whether the serological anomalies observed in the previous study were due to changes in the LPS of $P$. aeruginosa, and to characterise the serological determinants of PA and NT strains in CF. This involved: (1) the isolation of two serological variants (one PA, the other NT) from two O-typable strains; (2) a comparison of their serological properties with the parent strains; and (3) the use of antisera against the variants for the detection of serologically atypical cultures from CF sputum.

\section{Materials and methods}

\section{Strains of Pseudomonas aeruginosa}

The origin and properties of the four experimental strains are given in table I. The $17 \mathrm{O}$-serotype strains of the International Antigenic Typing Scheme (IATS) for the production of O-typing sera were described by Liu et al. (1983), and O-factor strains O2b and O5d (Véron, 1961) were used to subdivide IATS serogroups $O 2$ and O5. From $115 \mathrm{CF}$ patients attending an out-patients' 
clinic, 553 cultures were isolated. Sputum was digested with pancreatin (Rawlins, 1953), and cultured on Pseudomonas Isolation Agar (Difco) and King's 'A' agar (King et al., 1954). Cultures were identified as $P$. aeruginosa by their production of oxidase enzyme and pyocyanin, and their colonial appearance on King's ' $A$ ' agar.

\section{Media}

Tryptone Soy Broth (Oxoid) and Tryptone Soy Agar (Oxoid) were used throughout for liquid and solid culture respectively.

\section{Bacteriophages}

The 20 phages of the routine phage-typing set were as described by Asheshov (1974), and the LPS specific phages E79 and PLS1 (Jarrell and Kropinski, 1976 and 1977) were obtained from Dr A. M. Kropinski, Queen's University, Kingston, Ontario, Canada. Phage-resistant variants of strains were selected by the procedure of Bradley and Pitt (1974).

\section{Pyocin typing}

Cultures were typed by the method of Govan (1978).

\section{Preparation of antisera.}

The methods described by Pitt and Erdman (1978) were used for the preparation of $\mathrm{O}$-antisera, for agglutination tests and for the absorption of antibody from serum.

\section{Serum sensitivity test}

Cultures were tested for sensitivity to the bactericidal action of normal human serum by the method of Penketh et al. (1983).

\section{Isolation of lipopolysaccharide (LPS)}

LPS was isolated from whole acetone-dried cells by the method of Darveau and Hancock (1983). Total carbohydrate was measured by the anthrone reaction (Trevelyan and Harrison, 1952), total protein by the method of Lowry et al. (1951), and 2-keto-3-deoxyoctonate (KDO) by the procedure of Osborn (1963).

\section{SDS polyacrylamide gel electrophoresis (SDS- $P A G E$ )}

This was performed by the method of Palva and Mäkelä (1980) with a $12.5 \%$ acrylamide resolving gel. LPS ( $10 \mu \mathrm{l}$ containing $5 \mathrm{mg} / \mathrm{ml}$ ) was applied to each lane. Protein bands were stained with Coomassie brilliant blue $0.1 \% \mathrm{w} / \mathrm{v}$ in acetic acid $10 \% \mathrm{v} / \mathrm{v}$ and methanol $25 \% \mathrm{v} / \mathrm{v}$. Gels were destained with the above solution without the stain. Carbohydrates were detected by the silver stain of
Tsai and Frasch (1982). Gels were calibrated with an Electrophoresis Calibration Kit (Pharmacia) consisting of standard proteins with mol. wt in the range $14400-$ 94000 .

\section{Indirect haemagglutination}

Sera were inactivated at $56^{\circ} \mathrm{C}$ for $30 \mathrm{~min}$ and absorbed with thrice-washed sheep red blood cells (SRBC) by adding $100 \mu$ l of serum to $0.9 \mathrm{ml}$ of SRBC suspension $10 \%$ $\mathrm{v} / \mathrm{v}$. LPS ( $50 \mu \mathrm{l}$ containing $1 \mathrm{mg} / \mathrm{ml}$ ) was added to $0.3 \mathrm{ml}$ of saline and $0.15 \mathrm{ml}$ of $10 \% \mathrm{SRBC}$ and the mixture was incubated at $37^{\circ} \mathrm{C}$ for $1 \mathrm{~h}$ with shaking in a water bath. The sensitised cells were washed thrice in saline by centrifugation at $1000 \mathrm{~g}$ for $10 \mathrm{~min}$ and resuspended in 5 $\mathrm{ml}$ of phosphate buffered saline (PBS) $0.002 \mathrm{M}, \mathrm{pH} 7.5$, containing bovine serum albumin (Armour Pharmaceutical Co. Ltd, Eastbourne, Sussex) $0.1 \%$ w/v. Control mixtures not containing antigen were included in each batch of tests. Sera were diluted serially in PBS-albumin by two-fold dilutions of $25 \mu \mathrm{l}$ in ' $U$ '-well microtitration trays (Dynatech), and 25- $\mu$ l volumes of sensitised SRBC were added to each of the serum and control wells. The trays were shaken gently and incubated first for $2 \mathrm{~h}$ at $37^{\circ} \mathrm{C}$ and then overnight at $4^{\circ} \mathrm{C}$.

\section{Results}

\section{Selection of variant strains}

The variant strain $7 / 1$ was selected from the reference phage propagating strain 7 by its resistance to phage 7 . Strain $7 / 1$ was classified as PA because it was strongly agglutinated by seven $\mathrm{O}$ typing antisera $(\mathrm{O} 1, \mathrm{O} 3, \mathrm{O} 5 \mathrm{~d}, \mathrm{O6}, \mathrm{O} 9, \mathrm{O} 10$ and O13); the parent strain 7 was agglutinated by serum O6 alone. Strain $7 / 1$ was sensitive to the bactericidal action of normal human serum, in contrast to the parent which was serum resistant. The pyocin type of both strains was identical; but the variant was not lysed by any of the typing phages and was insensitive to the LPS-specific phages E79 and PLS1 (table I).

The other variant strain (18S) was isolated from the same sputum specimen of a CF patient as a serum-resistant culture (18R) which was of serotype O5d. Strain 18S was fully serum-sensitive but was not agglutinated by any of the O-typing sera. It was assumed that $18 \mathrm{~S}$ was derived from $18 \mathrm{R}$ because, in serial subculture on agar, approximately 1 in 20 colonies reverted to serum resistance and expressed $O$ antigen 5d. Also, the opposite conversion of $18 R$ to $18 \mathrm{~S}$ occurred at a similar frequency. The pyocin type of $18 \mathrm{R}$ and $18 \mathrm{~S}$ was identical, and their phagetyping patterns were similar although only $18 \mathrm{~S}$ was 
Table I. Characteristics of reference strains of $P$. aeruginosa

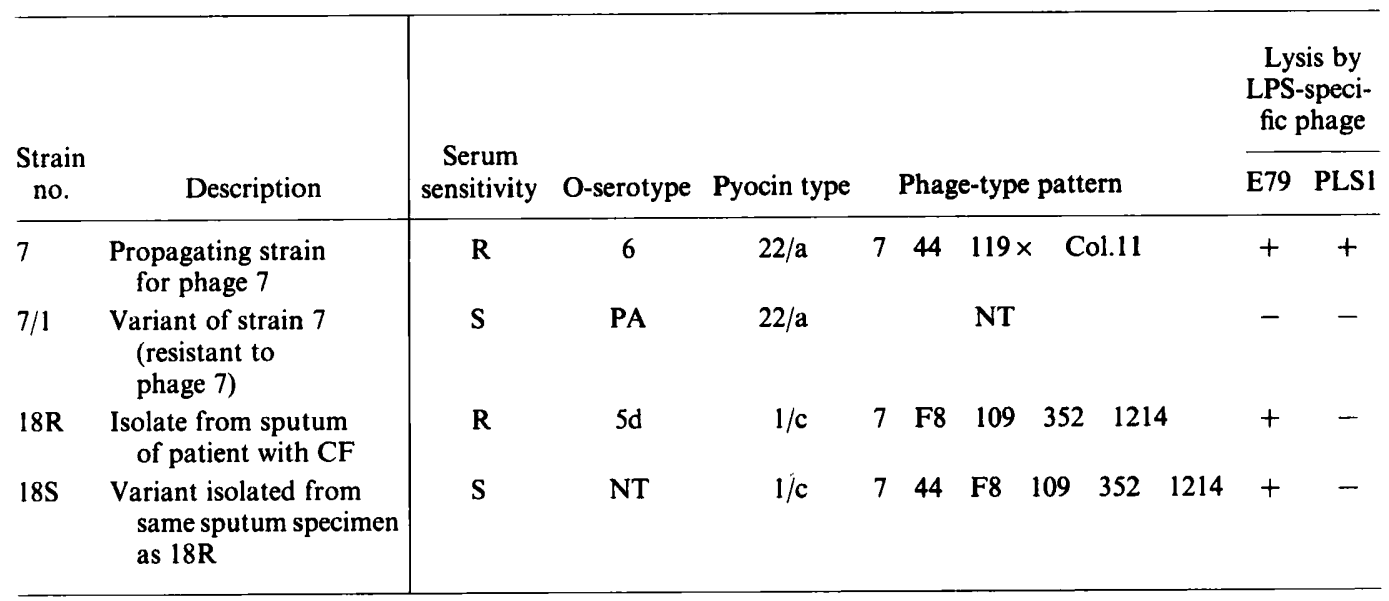

$\mathbf{R}=$ resistant, $\mathrm{S}=$ sensitive, to bactericidal action of normal human serum; $\mathrm{PA}=$ polyagglutinable (with antisera $\mathrm{O}$, O3, O5d, O6, O9, O10 and O13); NT = non-typable; LPS = lipopolysaccharide.

sensitive to phage 44. Both strains were lysed by the LPS-specific phage E79, but not by PLS1.

The four strains produced pyocyanin and fluorescein, and gave typical colonies on agar; no differences in biochemical activity were observed between the parent and variant strains. The variants grew less well in overnight broth culture than the parents (viable count 10-fold less), and broth cultures of the variants became granular after heating at $100^{\circ} \mathrm{C}$.

\section{Agglutination reactions of variant strains}

Antisera were raised against boiled cells of the four strains, and were tested by slide agglutination with each of the strains. Table II shows that serum to each of the parent strains contained agglutinin only to the homologous vaccine strain and its variant. The heterologous titres of the four antisera were at least 4-fold lower than their homologous reactions in repeated tests. Anti-18S serum cross reacted with each of the heterologous strains to the same titre, but the agglutination reactions were incomplete-a proportion of cells were not agglutinated and remained in suspension even after mixing for $5 \mathrm{~min}$ on the slide. The titres of unabsorbed and absorbed sera were reproducible; values did not vary more than two-fold in tests performed on two separate occasions.

Absorption of anti-7 serum with boiled or unheated cells of strain $7 / 1$ did not markedly reduce its homologous titre; in contrast, cells of strain 7 reduced the titre of anti- $7 / 1$ serum to $<10$. Likewise strain $18 \mathrm{R}$ completely absorbed the reaction of anti-
$18 \mathrm{~S}$ serum with the homologous vaccine strain. These results indicated that the variant antigens were present in the parent strains, but the latter did not induce agglutinating antibody to the variant antigens as efficiently as did the variant strains.

The O-antigen specificity of the four antisera, diluted to one-quarter of their homologous titres, was determined by agglutination tests with the reference O-type strains. Anti-7 serum reacted only with strain 06, which was the serotype of strain 7 .

Table II. Agglutination of parent and variant strains of $P$. aeruginosa by homologous and heterologous O-antisera before and after absorption with heterologous strains

\begin{tabular}{|c|c|c|c|c|c|}
\hline \multirow{2}{*}{$\begin{array}{l}\text { Antiserum } \\
\text { to strain }\end{array}$} & \multirow{2}{*}{$\begin{array}{l}\text { Absorbed with } \\
\text { suspension of }\end{array}$} & \multicolumn{4}{|c|}{$\begin{array}{c}\text { Agglutination titre* } \\
\text { with strain }\end{array}$} \\
\hline & & 7 & $7 / 1$ & $18 R$ & $18 \mathrm{~S}$ \\
\hline 7 (parent) & $\begin{array}{r}\text { nil } \\
7 / 1\end{array}$ & $\begin{array}{r}160 \\
80\end{array}$ & $\begin{array}{l}40 \\
-\end{array}$ & $\begin{array}{l}- \\
\cdots\end{array}$ & $\begin{array}{l}- \\
\ldots\end{array}$ \\
\hline $7 / 1$ (variant) & $\begin{array}{l}\text { nil } \\
7\end{array}$ & $\begin{array}{l}20 \\
-\end{array}$ & $\begin{array}{c}160 \\
-\end{array}$ & $\begin{array}{l}- \\
\cdots\end{array}$ & $\begin{array}{l}- \\
\cdots\end{array}$ \\
\hline $18 \mathrm{R}$ (parent) & $\begin{array}{r}\text { nil } \\
18 S\end{array}$ & $\begin{array}{l}- \\
\cdots\end{array}$ & $\begin{array}{l}- \\
\cdots\end{array}$ & $\begin{array}{l}80 \\
80\end{array}$ & $\begin{array}{l}10 \\
-\end{array}$ \\
\hline $18 \mathrm{~S}$ (variant) & $\begin{array}{c}\text { nil } \\
18 R\end{array}$ & $\begin{array}{l}20 \\
-\end{array}$ & $\begin{array}{l}20 \\
-\end{array}$ & $\begin{array}{l}20 \\
-\end{array}$ & $\begin{array}{l}80 \\
-\end{array}$ \\
\hline
\end{tabular}

$-=<10 ; \ldots=$ not done.

* Tested by slide agglutination. In repeated tests, the titres did not vary more than 2-fold from those stated (see Results). 
Table III. Percentage yield of lipopolysaccharide (LPS); and total carbohydrate, protein and KDO content of LPS

\begin{tabular}{|c|c|c|c|c|}
\hline \multirow[b]{2}{*}{ Strain } & \multirow[b]{2}{*}{ Yield of LPS* } & \multicolumn{3}{|c|}{ Analysis of LPS } \\
\hline & & Protein $\dagger$ & $\begin{array}{c}\text { Total } \\
\text { carbohydrate } \dagger\end{array}$ & KDO‡ \\
\hline 7 & $10 \cdot 5$ & $3 \cdot 8$ & 68 & $2 \cdot 7$ \\
\hline $7 / 1$ & $9 \cdot 5$ & $3 \cdot 3$ & 44 & $3 \cdot 6$ \\
\hline $18 \mathrm{R}$ & $8 \cdot 5$ & 1.4 & 44 & $2 \cdot 4$ \\
\hline $18 S$ & $4 \cdot 5$ & 1.8 & 38 & $3 \cdot 2$ \\
\hline
\end{tabular}

$\mathrm{KDO}=2$-keto-3-deoxyoctonate

* Percentage of dry weight of acetone-dried whole cells.

$\dagger$ Percentage of purified LPS.

$\ddagger$ Percentage of total carbohydrate.

Anti-7/1 serum gave weak reactions with type strains $\mathrm{O} 15$ and $\mathrm{O} 17$ but did not agglutinate any of the other type strains. Both anti-18R and anti-18S sera reacted with strain O5d (O serotype of 18R), and showed cross reactions with strains $\mathrm{O} 2$ and $\mathrm{O} 16$ which are known to be serologically related to type O5.

\section{Lipopolysaccharide of variant strains}

To identify the basis of the change in the expression of heat-stable surface antigens, the LPS of each strain was characterised. The yields of LPS expressed as a percentage of the dry weight of acetone-dried whole cells are given in table III. Strains 7 and 7/1 contained similar amounts of LPS, but strain $18 \mathrm{~S}$ yielded $47 \%$ less LPS than the parent strain 18R. Protein contamination was minimal; values were in the range $1.4 \%$ (for $18 \mathrm{R}$ ) to $3.8 \%$ (for strain 7). The total carbohydrate of the two variant strains was similar (38\% and $44 \%)$ but there was a considerable difference in yield between the parent strains $(44 \%$ and $68 \%)$. The carbohydrate content of LPS $7 / 1$ was approximately two-thirds that of LPS 7 , but the difference between LPS $18 \mathrm{R}$ and LPS $18 \mathrm{~S}$ was only $6 \%$. The percentage KDO content of the carbohydrate of the variant $7 / 1$ was higher than that of the parent strain, but $18 \mathrm{~S}$ had more KDO than $18 \mathrm{R}$.

A variety of bands was resolved by SDS-PAGE (see figure). A densely stained zone, apparently consisting of three bands, was given by LPS 7 (lane 2) in the region of the gel which corresponded to mol. wts c. 10000-17000 when compared with standard proteins. These bands were interpreted as possibly representing core components of LPS, because two of them were common to LPS $7 / 1$ and
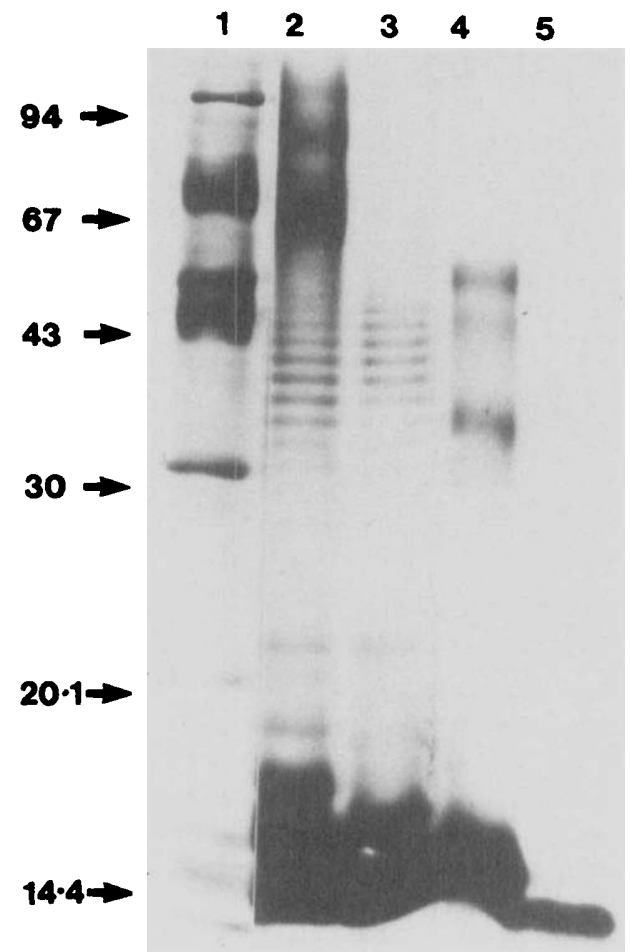

Fig. SDS-PAGE of lipopolysaccharide (LPS) from four strains of $P$. aeruginosa on $12.5 \%$ acrylamide gels. Samples contained 10 $\mu$ l of LPS $(5 \mathrm{mg} / \mathrm{ml})$ in buffer. Lane 1 , standard proteins; lane 2 , LPS 7; lane 3, LPS 7/1; lane 4, LPS 18R; lane 5, LPS 18S. Mol. wt $\left(10^{3}\right)$ markers are shown.

LPS 18R (lanes 3 and 4 respectively); but only one was present in the track of LPS 18S (lane 5). Narrow bands forming a regular ladder throughout the middle part of the gel were distinguishable in the tracks of LPS 7 and $7 / 1$; but the densely staining bands of high mol. wt (60000-95000), of LPS 7, were absent from the track of variant LPS $7 / 1$. The LPS of strain 18R (lane 4) did not exhibit molecular size heterogeneity, as evidenced by the lack of multiple banding; but two major bands corresponding to mol. wts $c .35000$ and 50000 were developed by the silver stain. These bands were not found in the track of the variant LPS 18S. No protein bands were detected in any of the LPS tracks on staining with Coomassie blue.

\section{Serological reactions of lipopolysaccharides}

The LPS of strain 7 adsorbed efficiently to sheep erythrocytes, and high homologous titres of haemagglutination with antisera were obtained (table IV) in tests repeated at least three times. The titres given by LPS $7 / 1$ were variable and appeared to be 
Table IV. Indirect haemagglutination of lipopolysaccharide (LPS) of parent and variant strains of $P$. aeruginos $a$ by homologous and heterologous $\mathbf{O}$ antisera

\begin{tabular}{|c|c|c|c|c|}
\hline \multirow{2}{*}{$\begin{array}{l}\text { Antiserum } \\
\text { to strain }\end{array}$} & \multicolumn{4}{|c|}{$\begin{array}{c}\text { Haemagglutination titre with LPS } \\
\text { of strain }\end{array}$} \\
\hline & 7 & $7 / 1$ & $18 R$ & $18 S$ \\
\hline 7 & 40960 & $40-80^{*}$ & 0 & $40-80^{*}$ \\
\hline $7 / 1$ & 640 & $40-2560^{*}$ & 0 & 20 \\
\hline $18 R$ & 0 & 0 & 5120 & 0 \\
\hline $18 \mathrm{~S}$ & 0 & $40-640^{*}$ & 5120 & 640 \\
\hline
\end{tabular}

* Range of titres in repeated tests. $0=<20$.

influenced by the batch of LPS used to sensitise the erythrocytes, because homologous titres ranged from 40 to 2560 . A similar variation was observed in tests with anti-18S serum and LPS $7 / 1$; but the homologous titres of the parent strains 7 and $18 R$ were reproducible. The results obtained by haemagglutination were in general agreement with those given by agglutination of whole cells (see table II), and confirmed that LPS $7 / 1$ was distinguishable from the parent LPS 7. Moreover, the partial serological relationship between the variant strains, as indicated by agglutination tests, was confirmed by the reaction of anti-18S serum and LPS $7 / 1$ in haemagglutination tests. The LPS of strain $18 \mathrm{R}$ gave the same titre with anti-18S serum, although the LPS of $18 S$ failed to react with antibody to $18 R$.

\section{Detection of antigenic variants in $C F$ isolates}

It was evident on examination of primary cul- tures of sputa that most patients were colonised by two or more colonial forms of $P$. aeruginosa. In total, 553 cultures of $P$. aeruginosa were isolated from specimens taken from $115 \mathrm{CF}$ patients on at least two separate occasions. These were tested for serum sensitivity, and were serotyped by agglutination with $\mathrm{O}$-antisera and with the two antisera to the variant strains $7 / 1$ and $18 \mathrm{~S}$. Table $V$ shows that 414 $(75 \%)$ of the isolates were fully sensitive to serum, and only $70(13 \%)$ were resistant; 69 were partially sensitive to serum, giving a 10 - to 1000 -fold decrease in viable count compared with a control.

The association of serum sensitivity and loss of O-specific reaction observed previously by Penketh et al. (1983) was confirmed with this series of cultures. O-typable cultures were most often serum resistant or only partially sensitive to serum. Amongst the 17 cultures which were fully sensitive to serum but reacted with a single $O$ serum, 6 were serotype $\mathrm{O} 11$ and were isolated from the same patient on repeated visits to the out-patients clinic; the other serotypes in this group were $03,06,09$, O10 and 016.

Approximately one-fifth of the cultures did not react with any of the O-antisera, and $84(69 \%)$ of 122 were serum sensitive. A number of these strains may have had specific $O$ antigens, but were not agglutinated because of their extreme mucoid nature $(35 \%)$ which made them non-emulsifiable in saline. Of the 553 isolates, $144(26 \%)$ were agglutinated by anti-7/1 (PA) serum alone, in contrast with 56 isolates $(10 \%)$ by anti-18S serum; but 147 cultures $(27 \%)$ were agglutinated by both sera. Three O-typable serum-resistant cultures gave a reaction with the PA serum (anti-7/1), and seven of the serum-resistant group which were O-non-typable were agglutinated by this serum. Statistical analysis of the data confirmed that most serum-

Table V. Sensitivity to normal human serum, and agglutination reactions, of 553 isolates of $P$. aeruginosa from $115 \mathrm{CF}$ patients

\begin{tabular}{l|lccccc}
\hline & \multicolumn{4}{|c}{ Number (percentage) of isolates in agglutination category } & Total \\
\cline { 2 - 6 } $\begin{array}{c}\text { Serum } \\
\text { sensitivity }\end{array}$ & O-typable & O-non-typable & anti-7/1 (PA) & anti-18S (NT) & $\begin{array}{c}\text { anti-7/1 and } \\
\text { anti-18S }\end{array}$ & $\begin{array}{c}\text { number (\%) } \\
\text { of isolates }\end{array}$ \\
\hline $\begin{array}{c}\text { Resistant } \\
\text { Partially } \\
\text { sensitive }\end{array}$ & 40 & 19 & 10 & 0 & 1 & $70(13)$ \\
Sensitive & 17 & 19 & 12 & 4 & 7 & $69(12)$ \\
Total & 17 & 84 & 122 & 52 & 139 & $414(75)$ \\
\hline
\end{tabular}

PA = polyagglutinable; NT = non-typable. 
resistant and partially resistant strains were $\mathrm{O}$ typable or O-non-typable, whereas strains which were agglutinated by either variant anti-serum were most often sensitive to serum $\left(\chi^{2}=193.03\right.$, d.f. $=8$, $\mathrm{p}<0.0005)$.

\section{Discussion}

Holloway and Cooper (1962) were the first to show that a somatic antigen of $P$. aeruginosa was altered by lysogenisation with phage. Subsequently, Liu (1969) and Bergan and Midtvedt (1975) demonstrated conversion of the $O$ serogroup of reference strains by phage. We used a typing phage to isolate resistant variants of its homologous propagating strain, and chose a culture which had become agglutinable by several additional antisera. Changes in surface structure of this induced variant $7 / 1$ were indicated by loss of susceptibility to the six phages that were active on the parent strain, including two phages specific for lipopolysaccharide. In contrast, the antigenic change of strain $18 \mathrm{~S}$ from serotype $\mathrm{O} 5 \mathrm{~d}$ to $\mathrm{O}$ non-typable, after selection by its sensitivity to serum, was accompanied by only a minor alteration in its phage susceptibility.

We can provide no explanation for the weak reaction of anti-7/1 serum with the type strains 015 and $\mathrm{O} 17$ and this requires further investigation. However, as anti-7/1 serum did not agglutinate other type strains, this suggests that PA antigen was not exposed on the surface of these strains. The fact that the vaccine strain $7 / 1$ was agglutinated by several O-typing sera is consistent with the finding of Pitt and Erdman (1978) who showed that some $\mathrm{O}$-sera contained antibodies to both PA and $\mathrm{O}$ antigens. It may be, therefore, that although PA antigen is immunogenic in some serotype strains the PA reactions are obtained only with strains lacking O-type-specific components in their LPS.

Meadow et al. (1984) described three phageresistant mutants of an O-typable strain which reacted with four $\mathrm{O}$ antisera, and these mutants differed from the parent strain in their composition. We performed only a limited analysis of the LPS of our parent and variant strains, but differences in gross composition were observed (table III and figure). Yields of LPS from the variant strains had been low in our preliminary studies, by the phenolwater method of Westphal and Jann (1965); but the introduction of the extraction procedure of Darveau and Hancock (1983) in the present investigation gave increased yields of LPS from all strains; the lowest yield was obtained from variant $18 \mathrm{~S}$ which had apparently the most rough LPS.

Electrophoresis in SDS-polyacrylamide gels is being increasingly applied to the analysis of molecular size heterogeneity of LPS (Jann et al., 1975; Palva and Mäkelä, 1980; Kuzio and Kropinksi, 1983). Palva and Mäkelä (1980) demonstrated a linear relationship between the mobility of individual core components and their concentration. We used this method to compare directly the separation profiles of the LPS of our parent and variant forms of $P$. aeruginosa. The wild-type LPS of parent strain 7 gave numerous silver staining bands over a wide range of mol. wt but these were absent in the LPS of the other O-typable strain 18R. The lack of staining of bands in the latter may be due to the scarcity of periodate-sensitive groups in the LPS of serotype O5d, as suggested by Meadow et al. (1984) to explain a similar lack of banding observed with a strain of serotype O3.

It appears therefore that the variant forms of both parent strains had lost the $\mathrm{O}$-specific determinants associated with the high-mol.-wt region of the LPS which corresponds to O-specific side chains. LPS $7 / 1$ was not grossly altered, as visualised by SDS-PAGE; but the evidence of loss of somatic phage receptors, its acquired susceptibility to normal serum, and its increased range of agglutinability with O-typing sera, would suggest that the surface architecture of the strain had been modified. A function of side chains of LPS is to protect the bacterial surface from the lytic effects of complement, which is activated by lipid A embedded deeper in the outer membrane (Mäkelä et al., 1980). The variant strain's sensitivity to serum, therefore, may be a consequence of the loss of protective $\mathrm{O}$ specific side chains. The bacterial agglutination results are also consistent with a hypothesis of loss of O-specific antigens; and the absorption of antibody by parent and variant cells (table II) suggests that antigens common to both were exposed as a result. In particular, absorption of antiserum to the variant $7 / 1$ with the parent strain reduced its homologous titre. This suggests that the variant was present on the parent strain, although the latter gave only low-titre agglutination with the variant antiserum and was also a specific serotype, O6. Indirect haemagglutination tests confirmed the serological relationship between the pairs of strains; but, as the variant antigens adsorbed poorly to red cells, further investigation of the serological analysis of the purified LPS is necessary.

The findings of Meadow et al. (1984) indicated variable adsorption of LPS to erythrocytes; and they found that envelope fractions of mutant strains with defective LPS gave low titres by haemagglutination, compared with LPS from the wild-type strain which contained high-mol.-wt polysacchar- 
ides. Our two variant antisera detected defective antigens in more than one-half of the isolates from $\mathrm{CF}$; and this finding correlated with the serumsensitivity of the isolates. Nevertheless some serumsensitive cultures were not agglutinated by the antisera and these may represent different defective antigen phenotypes. In accord with this suggestion, Hancock et al. (1983) demonstrated considerable heterogeneity by SDS-PAGE in the core components of the LPS of $P$. aeruginosa from CF. A search for other antigen phenotypes, and comparison of the electrophoretic profiles of their LPS, may provide a basic scheme for the classification of these strains.

The emergence of O-antigen defective forms has been recognised in recurrent bacteriuria due to Escherichia coli (Lindberg et al. 1975). The original infecting strains of $E$. coli were serum resistant, had a normal LPS as determined by gross composition and yield, and were readily serogrouped by specific $\mathrm{O}$-antisera. These strains sometimes persisted in the bladder for several months and even years, but they progressively lost their $\mathrm{O}$-specificity and became serum sensitive. There was rarely extension of the infection into the blood stream, but despite intermittent antibiotic therapy the organisms persisted. This seems analogous with the role of $P$. aeruginosa

\section{REFERENCES}

Asheshov E H 1974 An assessment of the methods used for typing strains of Pseudomonas aeruginosa. In: Arseni A (ed) Proceedings of the 6th International Congress of Bacterio$\log y$, Leontiadi Medical Editions, Athens, pp 9-22.

bergan T, Midtvedt T 1975 Epidemiological markers for Pseudomonas aeruginosa. 4. Change of $\mathrm{O}$-antigen and phage sensitivity after phage infection in vitro and in vivo of Pseudomonas aeruginosa. Acta Pathologica Microbiologica Scandinavica B 83:1-9.

Bradley D E, Pitt T L 1974 Pilus-dependence of four Pseudomonas aeruginosa bacteriophages with non-contractile tails. Journal of General Virology 24:1-15.

Cryz S J, Pitt T L, Furer E, Germanier R 1984 Role of lipopolysaccharide in virulence of Pseudomonas aeruginosa. Infection and Immunity 44:508-513.

Darveau R P, Hancock R E W 1983 Procedure for isolation of bacterial lipopolysaccharides from both smooth and rough Pseudomonas aeruginosa and Salmonella typhimurium strains. Journal of Bacteriology 155:831-838.

Govan J R W 1978 Pyocin typing of Pseudomonas aeruginosa. In: Bergan T, Norris J R (eds) Methods in Microbiology. Vol 10. Academic Press, London pp 61-91.

Hancock R E W, Mutharia L M, Chan L, Darveau R P, Speert D P, Pier G B 1983 Pseudomonas aeruginosa isolates from patients with cystic fibrosis: a class of serum-sensitive, nontypable strains deficient in lipopolysaccharide $\mathbf{O}$ side chains. Infection and Immunity 42:170-177.

Holloway B W, Cooper G N 1962 Lysogenic conversion in in $\mathrm{CF}$, where a progressive antigenic change has accompanied increase of sensitivity to serum during the course of respiratory infections (Penketh et al., 1983).

The loss of O-specific side chains by $P$. aeruginosa in CF may result in a decrease of virulence; Cryz et al. (1984) showed that for burned mice a LPSdefective variant was 1000 -fold less virulent than its parent. The continued survival of these organisms in the CF lung is therefore paradoxical in that they may be avirulent, sensitive to serum and hypersensitive to antibiotics (Irvin et al., 1981) and yet contribute to mortality in CF patients (Penketh $e t$ al., 1983). Antigenic variation of $P$. aeruginosa in $\mathrm{CF}$ may occur as a result of a selective pressure of the host's immune response towards the typical antigens of the initial infecting strain. The emergence of variant strains with defective antigens may not be recognised immunologically and the lack of antibody response towards these antigens may facilitate the survival of these strains in the already diseased lung of the CF patient.

We thank Drs J. C. Batten and M. E. Hodson for access to the patients and Sister F. Duncan for the collection and dispatch of specimens. The work was funded in part by the Cystic Fibrosis Trust.
Pseudomonas aeruginosa. Journal of Bacteriology 84, 13211324.

Irvin R T, Govan J R W, Fyfe J A M, Costerton J W 1981 Heterogeneity of antibiotic resistance in mucoid isolates of Pseudomonas aeruginosa obtained from cystic fibrosis patients: role of outer membrane proteins. Antimicrobial Agents and Chemotherapy 19:1056-1063.

Jann B, Reske K, Jann K 1975 Heterogeneity of lipopolysaccharides. Analysis of polysaccharide chain lengths by sodium dodecyl sulphate-polyacrylamide gel electrophoresis. European Journal of Biochemistry 60:239-246.

Jarrell K, Kropinski A M B 1976 The isolation and characterization of a lipopolysaccharide-specific Pseudomonas aeruginosa bacteriophage. Journal of General Virology 33:99-106.

Jarrell K, Kropinski A M 1977 Identification of the cell wall receptor for bacteriophage E79 in Pseudomonas aeruginosa strain PAO. Journal of Virology 23:461-466.

King E O, Ward M K, Raney D E 1954 Two simple media for the demonstration of pyocyanin and fluorescin. Journal of Laboratory and Clinical Medicine 44:301-307.

Kuzio J, Kropinski A M 1983 O-antigen conversion in Pseudomonas aeruginosa PAO1 by bacteriophage D3. Journal of Bacteriology 155:203-212.

Lindberg U, Hanson L A, Jodal U, Lidin-Janson G, Lincoln K, Olling S 1975 Asymptomatic bacteriuria in schoolgirls. II. Differences in Escherichia coli causing asymptomatic bacteriuria. Acta Paediatrica Scandinavica 64:432-436.

Liu P V 1969 Changes in somatic antigens of Pseudomonas aeruginosa induced by bacteriophages. Journal of Infectious Diseases 119:237-246. 
Liu P V, Matsumoto H, Kusama H, Bergan T 1983 Survey of heat-stable major somatic antigens of Pseudomonas aeruginosa. International Journal of Systematic Bacteriology 33:256-264.

Lowry O H, Rosebrough N J, Farr A L, Randall R J 1951 Protein measurement with the Folin phenol reagent. Journal of Biological Chemistry 193:265-275.

Mäkelä P H et al. 1980 Evasion of host defences. In: Smith H, Skehel J J, Turner M J (eds) The molecular basis of microbial pathogenicity. Verlag Chemie $\mathrm{GmbH}$, Weinheim pp 175197.

Meadow P M, Rowe P S N, Wells P L 1984 Characterization of polyagglutinating and surface antigens in Pseudomonas aeruginosa. Journal of General Microbiology 130:631-644.

Osborn M J 1963 Studies on the Gram-negative cell wall. 1. Evidence for the role of 2-keto-3-deoxyoctonate in the lipopolysaccharide of Salmonella typhimurium. Proceedings of the National Academy of Sciences of the USA 50:499-506.

Palva E T, Mäkelä P H 1980 Lipopolysaccharide heterogeneity in Salmonella typhimurium analyzed by sodium dodecyl sulphate/polyacrylamide gel electrophoresis. European Journal of Biochemistry 107:137-143.

Penketh A, Pitt T, Roberts D, Hodson M E, Batten J C 1983 The relationship of phenotype changes in Pseudomonas aeruginosa to the clinical condition of patients with cystic fibrosis. American Review of Respiratory Diseases 127:605-608.

Pitt T L 1981 A comparison of flagellar typing and phage typing as means of subdividing the $\mathrm{O}$ groups of Pseudomonas aeruginosa. Journal of Medical Microbiology 14:261-270.

Pitt T L, Erdman Y J 1978 The specificity of agglutination reactions of Pseudomonas aeruginosa with $\mathrm{O}$ antisera. Journal of Medical Microbiology 11:15-23.

Rawlins G A 1953 Liquefaction of sputum for bacteriological examination. Lancet 2:538-539.

Trevelyan W E, Harrison J S 1952 Studies on yeast metabolism. 1. Fractionation and microdetermination of cell carbohydrates. Biochemical Journal 50:298-303.

Tsai C M, Frasch C E 1982 A sensitive silver stain for detecting lipopolysaccharides in polyacrylamide gels. Analytical Biochemistry 119:115-119.

Véron M 1961 Sur l'agglutination de Pseudomonas aeruginosa: subdivision des groupes antigeniques $0: 2$ et. 0:5. Annales de l'Institut Pasteur 101:456-460.

Westphal O, Jann K 1965 Bacterial lipopolysaccharides. Extraction with phenol-water and further applications of the procedure. Methods in Carbohydrate Chemistry 5:83-91. 